\title{
Analysis of the shading of the development area of different cities in one light district
}

\author{
Natalya Bessonova ${ }^{1}$, Tatiana Germanova ${ }^{1, *}$ \\ ${ }^{1}$ Tyumen Industrial University, Institute of Service and Industry Management, 2, Lunacharsky str., \\ 625001, Tyumen, Russia
}

\begin{abstract}
The purpose of this work is to compare the insolation regime of the built-up territories of different cities of the same city in the same administrative region by light climate. The study was conducted in the Citis: Solaris software package. Based on the calculation results, models of shading the territory were built, and a conclusion was drawn on the differences in insolation in these cities.
\end{abstract}

\section{Introduction}

The current level of development of urban construction is inextricably linked with an increase in the density and number of storeys of buildings under construction, but with the preservation of safe and comfortable living conditions for the population. One of the factors ensuring health and comfort in urban spaces and premises of buildings is insolation [1]. The duration of insolation primarily depends on the geographical location of the city, namely, on the administrative region for the light climate resources, the distribution of which is according to SP 52.13330.2016 "Natural and artificial lighting". The administrative regions of the Russian Federation are grouped into light climate resources by the criterion of the total amount of illumination entering the room during the year.

The distribution of solar radiation in Russia can be seen on Fig. 1.

\footnotetext{
*Corresponding author: sheneps@mail.ru
} 


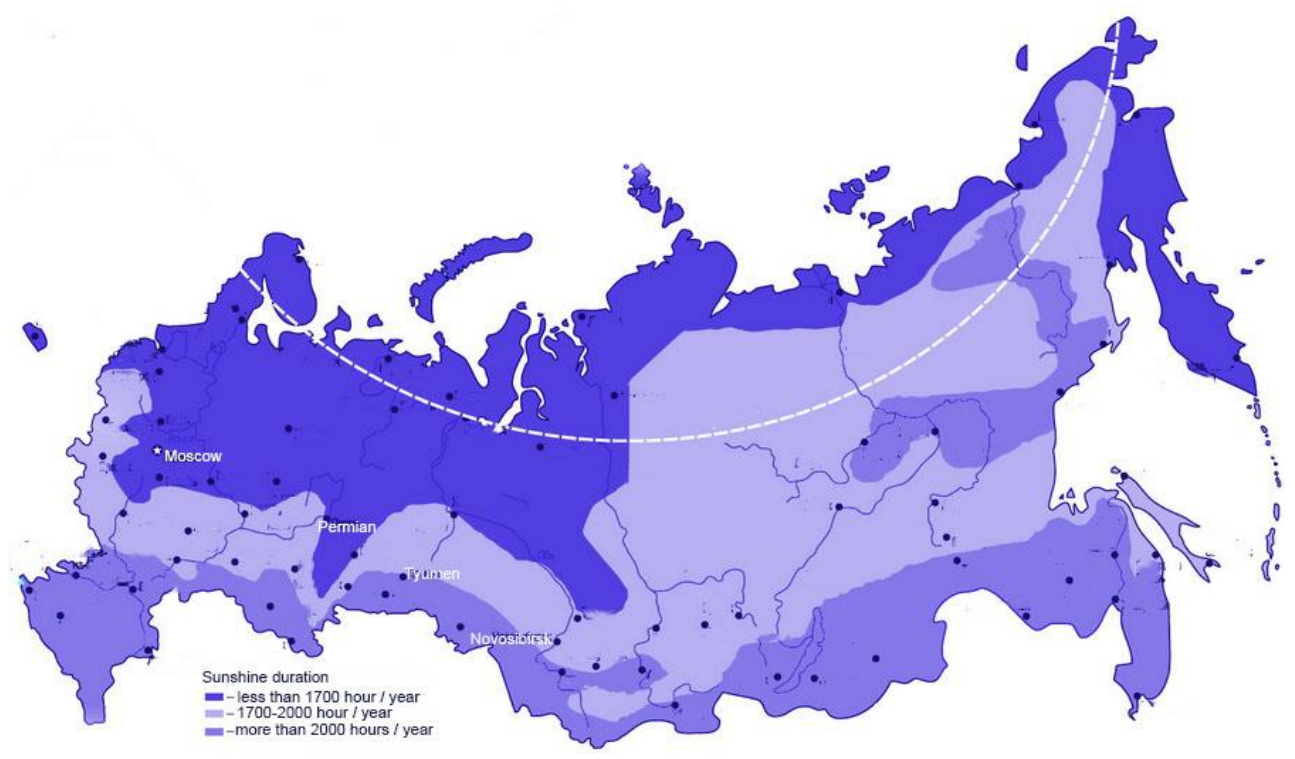

Fig. 1. Map of the insolation of the Russian Federation.

According to the light climate resources, administrative regions are divided into 5 groups. On the territory of such groups, their own territorial sanitary standards can be adopted to maintain the optimal duration of insolation. Such documents are lost legal force on the territory of other constituent entities of the Russian Federation. These documents include the "Norms of outdoor lighting of urban and rural settlements. TSN 23-330-2002 Khanty-Mansi Autonomous Okrug ", as well as" Natural, artificial and combined lighting. MGSN2.06-99."

\section{Methodology}

When erecting new buildings and structures on the territory of an existing development, the lighting indicators of the territory and buildings should remain at the standard level. The gap between the buildings is determined on the basis of fire safety requirements and the conditions for ensuring standard values of insolation and illumination (Table 1).

Table 1. The smallest distances between buildings according to the lighting conditions.

\begin{tabular}{|l|c|c|c|c|c|c|}
\hline \multirow{2}{*}{ Indicator (distance) } & \multicolumn{5}{|c|}{ Distance (m) between buildings (number of storeys) } \\
\cline { 2 - 8 } & 5 & 9 & 12 & 16 & 22 & 23 \\
\hline $\begin{array}{l}\text { Between the long sides of buildings with a } \\
\text { length of } 150 \mathrm{~m}\end{array}$ & 27 & 48 & 64 & 74 & 90 & 95 \\
\hline Between tower buildings (length <150 m) & & 42 & 52 & 60 & 70 & 72 \\
\hline $\begin{array}{l}\text { Between the long sides of buildings and } \\
\text { the ends of buildings with windows }\end{array}$ & 15 & 28 & 32 & 35 & 38 & 40 \\
\hline $\begin{array}{l}\text { Between the ends of buildings without } \\
\text { windows of living rooms }\end{array}$ & \multicolumn{7}{|l|}{ According to the standards of fire distances } \\
\hline
\end{tabular}

If the third building is located perpendicular to the ends of two parallel buildings, the distance between the latter should be increased by $20 \%$. with a complex configuration of buildings, the distances between them are determined by calculation taking into account the norms of natural lighting 
The basic requirements for insolation are detailed in [1,2].

Year-round shading of the facades of buildings and residential areas is not allowed. Semi-annual shadows (from September 22 to March 22) should not exceed 10\% of the total area free of development from the territories of residential areas, complexes of medical treatment and rehabilitation institutions in areas located south of $58^{\circ} \mathrm{N}$ and $20 \%$ north of $58^{\circ} \mathrm{N}$.

In the case of buildings with 9 floors or more, one-time intermittent insolation of residential premises is allowed provided that the total duration of insolation during the day is increased by 0.5 hours for each zone, respectively.

One of the favorable factors of solar radiation is the bactericidal and biological effect on the sanitary - hygienic conditions in the premises in the form of the destruction of microorganisms and the slowdown of their development.

Compliance with the standard time indicators of insolation for rooms allows minimizing the room overheating in summer from the heat that enters the room when exposed to sunlight through translucent structures [3, 4].

Actual insolation depends on the orientation and configuration of the building, window openings, the position of the design room, balconies and loggias.

The calculation of the insolation duration of buildings and territories is carried out using the Citis: Solaris software package. Calculation is made for any geographical coordinates and for the required date. In this program, there are opportunities for creating, editing, copying objects, changing their spatial position, as well as displaying constructed objects in the form of three-dimensional models.

The results of the calculation of insolation are visually presented in the form of graphs and in the form of a plan with the calculated parameters of objects and territories.

\section{Results}

According to the light climate resources, the subjects of the Russian Federation are divided into groups. According to this distribution, the 1st administrative group includes the following administrative regions: Vladimir, Kaluga, Kamchatka, Kemerovo, Krasnoyarsk (north of $63^{\circ} \mathrm{N}$ ), Kurgan, Moscow, Nizhny Novgorod, Novosibirsk, Omsk, Perm, Ryazan, The Republic of Bashkortostan, the Republic of Mordovia, the Republic of Tatarstan, the Republic of Sakha (Yakutia) (north of $63^{\circ} \mathrm{N}$ ), Sverdlovsk, Smolensk, Tula, Tyumen regions, Udmurt Republic, Khabarovsk Territory (north of $55^{\circ} \mathrm{N}$ ), Chelyabinsk Region Chu Your Republic, Chukotka Autonomous Okrug.

For the study, we selected the capital cities of the regions located in one group according to the light climate: Perm, Tyumen, Novosibirsk.

Perm is located in the east of the European part of Russia, in the Urals, on the banks of the Kama River. It serves as a transport hub on the Trans-Siberian Railway, it is also a river port, has the status of a city of regional significance and an urban district. A large diversified industrial, scientific, cultural and logistics center of the Urals, with a population of 1.53 million people for 2019 .

The city of Novosibirsk is located on both banks of the Ob River next to the Novosibirsk reservoir formed on the Ob, blocked by the dam of the Novosibirsk hydroelectric station. The territory of the city is $502.7 \mathrm{~km}^{2}$. From north to south, from Zaeltsovsky Park to Morsky Prospekt, the city stretches for 43 kilometers, from west to east its length is 25 kilometers. Population for 2019 It is 1.613 million people.

Tyumen is located in the south of Western Siberia, in the Asian part of Russia, on the banks of the Tura River. Detailed climatic and geographical characteristics of the city are highlighted in [5]. The population for 2019 is 788 thousand people. 
In the cities under study, the central (historical) development zone is well distinguished, characterized by the preservation of unique historical buildings, as well as high-density public and business buildings. Then follows the territory adjacent to the center, combining the development of residential and public-business buildings. As well as a residential development belt, characterized by different floors of buildings.

In all the cities represented there is perimeter development, it is characterized by the placement of houses along the red lines of the streets that border the microdistrict. This building technique is most architecturally simple. And it is precisely with such a building that there is a possibility of the occurrence of sealing (point building) in free territories $[6$, 7].

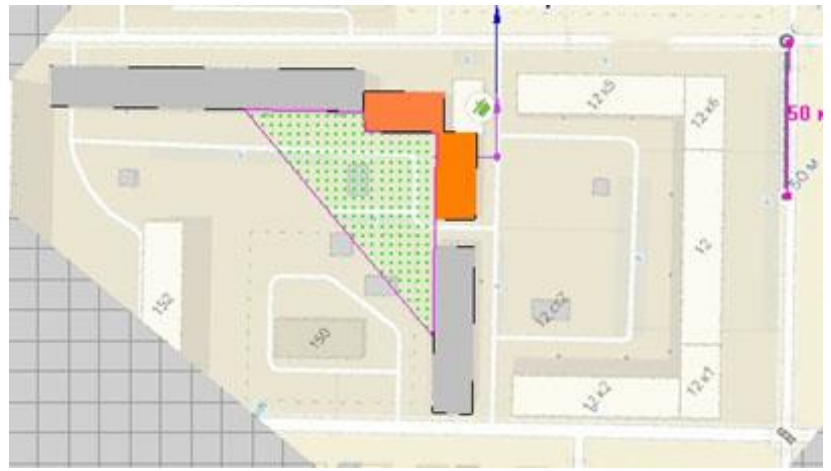

Fig. 2. Model of the investigated standard building.

In these building examples, it is possible to place a corner building between existing buildings (drawing of the analyzed place). The calculation of the insolation of the territory was carried out using the Citis Solaris program for the standard date for this light region April 22.

For an extended analysis of the insolation of the territory, the calculation was carried out with a change in the direction of the studied territory to the cardinal (Fig.3).

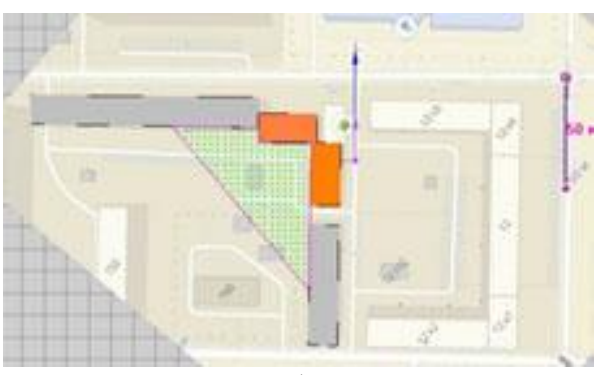

a)

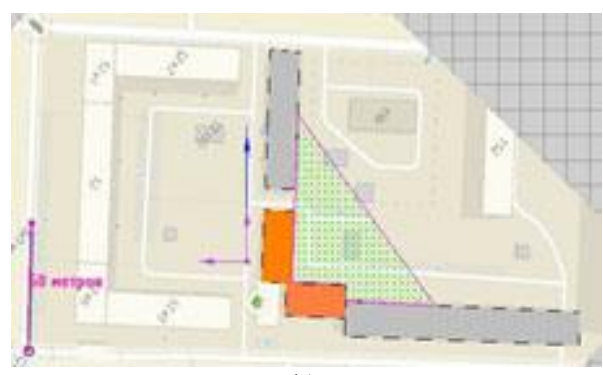

b)

Fig. 3. Orientation of the study area.

With option a) indicated in Fig. 3, shading of territories in cities occurs as follows (Fig.4, 5, 6).

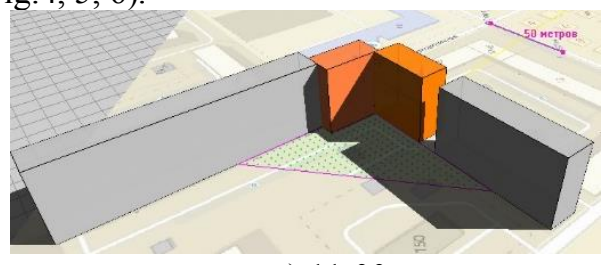

a) 11:00

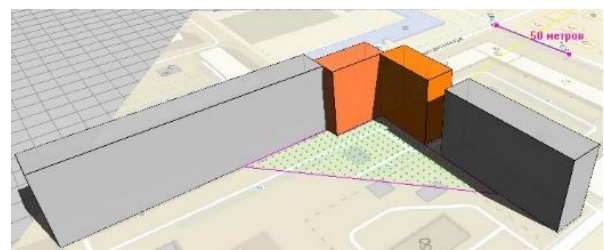

b) 13:00 
Fig. 4. Territory shading model for the first building orientation option in Novosibirsk.

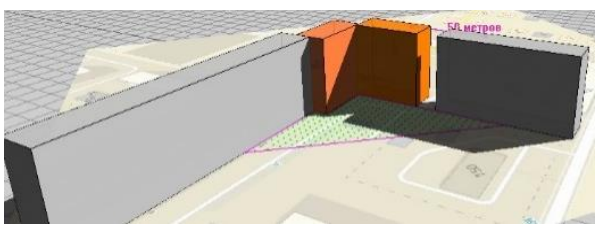

a) 11:00

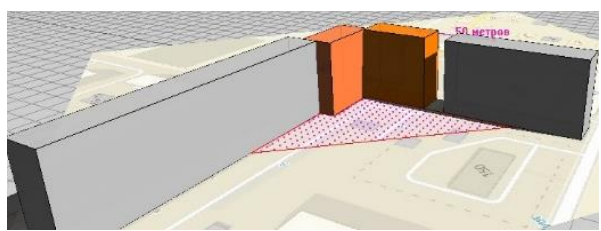

b) 13:00

Fig. 5. Territory shading model for the first building orientation option in Permian.

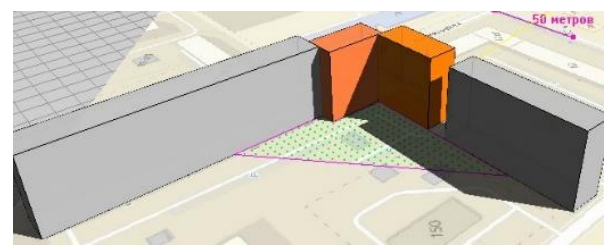

a) 11:00

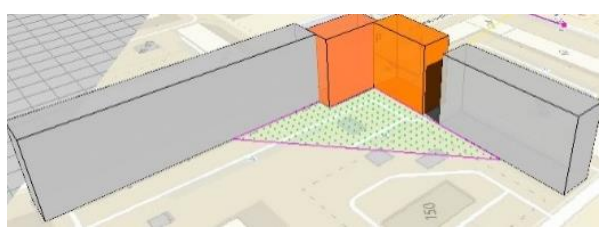

b) 13:00

Fig. 6. Territory shading model for the first building orientation option in Tyumen.

With option b) indicated in Fig. 3, shading of territories in cities occurs as follows (Fig. 7, 8, 9)

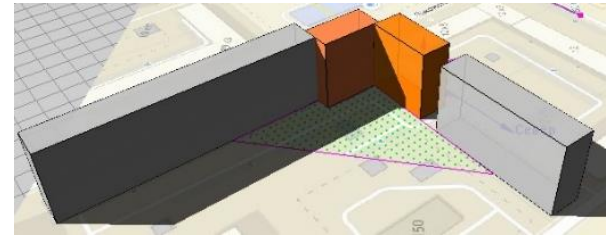

a) 11:00

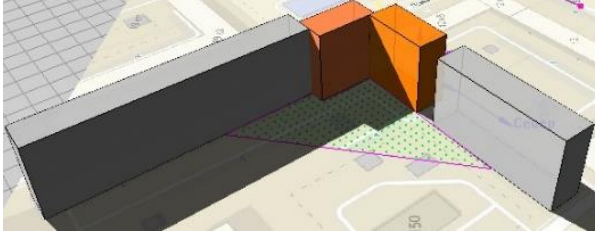

b) $13: 00$

Fig. 7. Territory shading model in the second building orientation variant in Novosibirsk.

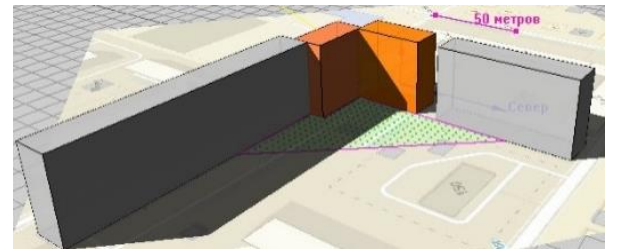

a) 11:00

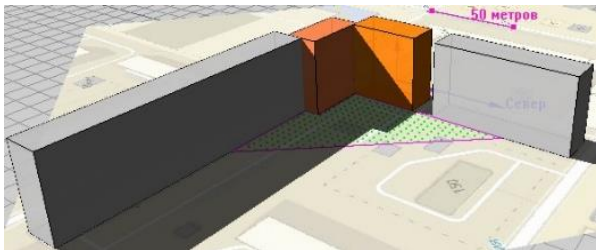

b) 13:00

Fig. 8. Territory shading model in the second building orientation variant in Permian.

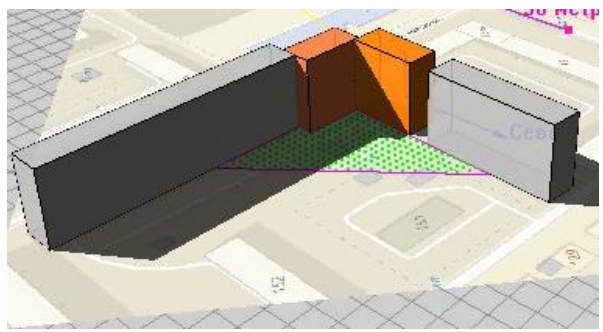

a) 11:00

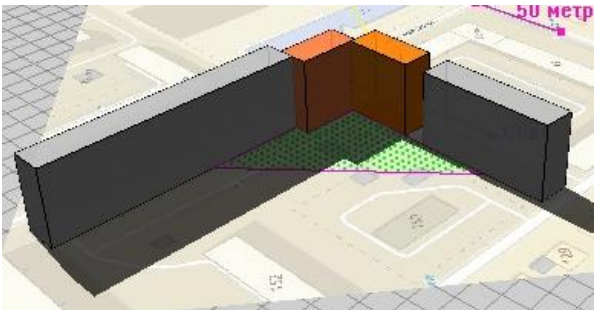

b) $13: 00$ 
Fig. 9. Territory shading model in the second building orientation variant in Tyumen.

Two times are indicated in Fig.4, 5, 6 and Fig.7, 8, 9: 11:00 and 13:00, according to the results of calculating insolation after 13:00, there is either no shading of the territory (location in the first version), or the territory is completely shaded (in the second construction location).

\section{Conclusion}

The requirements for the insolation of the territory in one administrative region are the same for all subjects of this region. But according to the results of a study of the built-up area for three subjects of one administrative district, it is clear that there are significant differences between the cities represented. This is primarily due to the geographical location of cities, namely, it depends on the local latitude. Therefore, the obtained data must be taken into account in each specific case of the built-up territories and used for rationing local territorial norms.

Detailed studies of the insolation of the territory are important not only for residential development, but also for facilities where it is necessary to comply with the standards of insolation, for example, for the territories of kindergartens, schools, boarding schools, hospitals. And this will positively affect the health of the population and children.

\section{References}

1. T. Germanova, N. Bessonova, IOP Conference Series: Earth and Environmental Science (2018)

2. T. Germanova, N. Bessonova, I. Davydova, MATEC Web of Conferences (2017)

3. E. Loiseau, G. Junqua, P. Roux, V. Bellon-Maurel, Journal of Environmental Management 112, 213-225 (2012)

4. I. Sarbu, C. Sebarchievici, Solar Heating and Cooling Systems, 13-28 (2017)

5. N. Bessonova, T. Germanova, Scientific and Technical Gazette Volga 6, 153-156 (2013)

6. E. Nault, P. Moonen, E. Rey, M. Andersen, Building and Environment (2017)

7. N. Bessonova, T. Germanova, Bulletin of Perm National Research Polytechnic University. Applied Ecology. Urbanity 1(13), 124-128 (2014) 